\title{
RANCANG BANGUN SISTEM INFORMASI PENGOLAHAN IKAN UNTUK KETERTELUSURAN DENGAN QR CODE
}

\author{
I Gede Sujana Eka Putra ${ }^{1)}$ Ni Luh Putu Labasariyani ${ }^{2)}$ \\ Program Studi Teknik Informatika, STMIK STIKOM Indonesia, Denpasar ${ }^{1) 2)}$ \\ sujanaekaputra@stiki-indonesia.ac.id ${ }^{1)}$ labasari@stiki-indonesia.ac.id²)
}

\begin{abstract}
Background of research is human errors in manual data recording, less accurate and data searching requires several time, thus cause difficulties in traceability system, while traceability is to collect product history from receipt of raw materials, processing, packaging until product delivery to customer. The purpose of this research is to design, and develop information system in fish processing to assist traceability of seafood product from receiving, processing until shipping to customer. System have feature to print QR Code label to put in products, which is readability through label scanning, in packaging stage and product shipments. Information label consist of product information,, species type, grade, and weight, supplier information, processing date, and fishing location. System design consist of feasibility study, data collection, system analysis, system design, and development, testing and implementation. Through the summary transaction module, fish processing can be traced from the beginning, starting from the stage of receiving, cutting, retouching to packaging. The QR code stores information where input data is faster through scanning. The use of internal lot codes, makes it easier to trace fish resources at each stage of fish processing, which consists of the code of the fish catch area, supplier code, and fish processing date.
\end{abstract}

Keywords: Traceability, QR Code, Data Management, Information System

\begin{abstract}
ABSTRAK
Latar belakang penelitian ini adalah banyaknya kesalahan dalam input data manual, ketidakakuratan dan pencarian data yang memerlukan waktu yang lama, kesulitan dalam sistem penelusuran dimana penelusuran sebagai kegiatan mengumpulkan data riwayat produk dari penerimaan bahan baku, pengolahan, pengemasan sampai pengiriman ke pelanggan.Tujuan penelitian ini adalah untuk merancang, dan membangun sistem informasi pengolahan ikan untuk membantu penelusuran produk perikanan dari awal sampai akhir. Sistem menyediakan fitur untuk print label QR Code untuk ditempel pada kemasan produk yang dapat dibaca oleh alat pemindai dalam pengemasan maupun pengiriman produk. Informasi label terdiri dari informasi produk, jenis spesies ikan, jenis, grade dan berat, informasi pemasok, tanggal pengolahan dan lokasi penangkapan ikan. Perancangan terdiri dari studi pendahuluan, pengumpulan data, analisa sistem, perancangan sistem dan pengujian dan implementasi sistem. Melalui modul summary transaction, dapat di telusuri pengolahan ikan dari awal mulai dari tahap penerimaan, pemotongan, retouching sampai pengemasan. Kode QR menyimpan informasi sebagai kode untuk scanning tahap pengolahan lanjutan, proses penginputan data lebih cepat melalui pemindaian maka data ikan sudah otomatis tercatat pada sistem. Penggunaan kode internal lot, memudahkan dalam melakukan penelusuran sumber ikan pada setiap tahap pengolahan ikan, yang terdiri dari kode wilayah tangkapan ikan, kode supplier, dan tanggal pemrosesan ikan.
\end{abstract}

Kata Kunci: Penelusuran, QR Code, Manajemen Data, Sistem Informasi

\section{PENDAHULUAN}

Teknologi informasi sebagai salah satu alat untuk memudahkan dalam pencatatan transaksi untuk proses ketertelusuran. Sistem ketertelusuran diperlukan dalam rantai distribusi produk pangan karena kualitas dan keamanan produk sebagai hal yang penting bagi konsumen. Ketertelusuran sebagai kemampuan sistem untuk menelusuri bahan baku produk pangan, termasuk pakan maupun bahan tambahan yang digunakan dalam seluruh mata rantai produksi, proses pengolahan hingga distribusi, kejelasan asal, perlakuan atau riwayat produksi suatu produk 
secara cepat dan efisien terhadap suatu produk sepanjang titik-titik kritis asal maupun tujuan produk dalam rangka terjaminnya keamanan produk pangan tersebut (Dwiyitno, 2016). Ketertelusuran sebagian besar telah dianggap sebagai persyaratan teknis untuk bisnis untuk memenuhi peraturan pemerintah tentang keamanan makanan, penarikan makanan (product recall), dan pelabelan untuk identifikasi negara asal produk makanan (Tamm dkk., 2016).

Keamanan pangan bersifat dinamis dan bermanfaat baik dalam jangka waktu panjang maupun jangka waktu pendek. Ditolaknya produk perikanan Indonesia oleh Amerika Serikat merupakan salah satu bukti masih kurangnya aplikasi keamanan pangan di Indonesia. Selain itu maraknya kejadian keracunan makanan yang mengakibatkan korban harus dirawat di rumah sakit maupun meninggal dunia juga menambah catatan buruk aplikasi keamanan pangan Indonesia. Mengutip data dari WHO, menunjukkan bahwa pada tahun 2005 1,8 juta orang meninggal karena diare dan kontaminasi air minum, yang terjadi pada negara berkembang dan negara maju. Amerika Serikat mengalami 76 juta kasus keracunan makanan setiap tahun, 325 orang dirawat, dan 5000 orang meninggal dunia. Data Badan Pengawasan Obat dan Makanan Indonesia pada 2010 juga menunjukkan tentang kasus keracunan makanan di Indonesia yang memakan korban 3050 orang dan 17 orang diantaranya meninggal dunia (Asosiasi Laboratorium Pangan Indonesia, 2011). Keracunan makanan lebih banyak diakibatkan oleh infeksi atau intoksikasi mikroorganisme. Begitu pentingnya keamanan produk pangan bagi konsumen mengharuskan perusahaan pengolahan makanan/perikanan untuk menjaga kualitas produk dan menerapkan sistem ketertelusuran.

Kondisi yang ada saat ini di lapangan, beberapa perusahaan pengolahan ikan masih menggunakan formulir manual untuk mencatat data pengolahan perikanan, dimana cara manual menimbulkan resiko kesalahan pencatatan data, formulir dapat rusak akibat basah atau hilang dan penelusuran data lebih sulit karena harus mencari dan mengumpulkan formulir yang sudah disimpan dalam jangka waktu lama. Rantai pasokan produk perikanan global cukup rumit dalam sistem ketertelusuran dalam mengidentifikasi distribusi produk yang kadangkala tidak diberikan identifikasi label dan salah dalam label (Hofherr dkk., 2016). Penggunaan sistem informasi untuk mengelola data pengolahan sangat menguntungkan perusahaan pengolahan dengan digunakannya pelabelan setiap hasil produksi, salah satunya menggunakan quick response code. Quick response code (QR Code) merupakan kode batang 2 dimensi dengan bentuk persegi dengan sejumlah simbol acak pada bagian tengahnya yang menjadi identitas pembeda, sebagai kode yang dapat menyampaikan informasi secara cepat dengan perolehan respons yang cepat pula. $Q R$ Code mampu menyimpan informasi secara horizontal dan vertical dan mampu menampung lebih banyak informasi dalam berbagai format dibandingkan dengan barcode, sehingga informasi sistem ketertelusuran dapat disimpan dengan baik pada kode tersebut (McMillin dkk., 2012).

\section{TINJAUAN PUSTAKA}

Sistem informasi selalu mengalami perkembangan yang pesat. Dalam penerapannya, sistem informasi memberikan kemudahan dan akurasi dalam pengelolaan data transaksi.

\section{Keamanan Pangan}

Teknologi informasi sebagai salah satu alat untuk memudahkan dalam pencatatan transaksi untuk proses ketertelusuran. Sistem ketertelusuran diperlukan dalam rantai distribusi produk pangan kualitas dan keamanan suatu produk seperti suatu hal yang penting bagi konsumen. Ketertelusuran sebagai kemampuan sistem untuk menelusuri bahan baku produk pangan, termasuk pakan maupun bahan tambahan yang digunakan dalam seluruh mata rantai produksi, proses pengolahan hingga distribusi, kejelasan asal, perlakuan atau riwayat produksi suatu produk secara cepat dan efisien terhadap suatu produk sepanjang titik-titik kritis asal maupun tujuan produk dalam rangka terjaminnya keamanan produk pangan tersebut (Dwiyitno, 2016). Ketelusuran ikan merupakan alat penting dalam keamanan makanan ikan dan alat pengenalan dalam penilaian keanekaragaman hayati dan perikanan (Ibáñez, 2015). Keamanan pangan bersifat dinamis dan bermanfaat baik dalam jangka waktu panjang 
maupun jangka waktu pendek. Keamanan pangan merupakan isu yang sangat penting dan harus dipraktekkan oleh industri pangan mulai dari sektor hulu hingga sektor hilir. "Tren penyakit bawaan pangan disebabkan oleh bakteri dan virus," ungkap dosen dan peneliti di Departemen Ilmu dan Teknologi Pangan IPB Prof Lilis Nuraida dalam Pelatihan Sistem Manajemen Keamanan Pangan ISO 22000:2005 di Bogor pada 24-25 September 2013 lalu. Mengutip data dari WHO, Lilis menunjukkan bahwa pada tahun 20051,8 juta orang meninggal karena diare dan kontaminasi air minum. Hal ini tidak hanya dialami oleh negara berkembang tetapi juga dialami oleh negara maju. Bahkan setiap tahun, Amerika Serikat mengalami 76 juta kasus keracunan makanan, 325 orang dirawat, dan 5000 orang meninggal dunia. Tidak berbeda jauh dengan Amerika Serikat, data dari Badan POM pada 2010 juga menunjukkan tentang kasus keracunan makanan di Indonesia yang memakan korban 3050 orang dan 17 orang diantaranya meninggal dunia. Infeksi membutuhkan waktu sekitar 8-24 jam dari kejadian untuk menunjukkan efek tertentu pada korban yang terinfeksi. Sedangkan untuk intoksikasi membutuhkan waktu yang lebih singkat. Keamanan mikrobiologi pangan bersifat dinamis (Asosiasi Laboratorium Pangan Indonesia, 2011). Virus dapat menginfeksi manusia melalui makanan, air, dan penularan dari manusia ke manusia. Sampai dengan saat ini belum ditemukan systemic surveilance untuk penyakit bawaan pangan yang disebabkan oleh virus. Penyakit bawaan pangan 42 persen terjadi pada home cooking (memasak sendiri di rumah untuk orang banyak), 28 persen karena makanan food industry, 27 persen karena makanan catering, dan 3 persen akibat makanan street food atau jajanan kaki lima (Asosiasi Laboratorium Pangan Indonesia, 2011)

\section{Ketertelusuran}

Ketertelusuran merupakan bagian penting dalam rantai distribusi suatu produk pangan sebagai salah satu upaya bagi terjaminnya kualitas dan keamanan suatu produk dan telah diterapkan pada banyak negara (Schröder, 2008). Uni Eropa mendefinisikan ketertelusuran produk pangan sebagai kemampuan suatu sistem untuk menelusuri bahan baku produk pangan, termasuk pakan maupun bahan tambahan yang digunakan dalam seluruh mata rantai produksi, pengolahan hingga distribusi (Dwiyitno,
2016). Sementara itu di Amerika Serikat, ketertelusuran diartikan sebagai metode penelusuran yang cepat dan efisien terhadap suatu produk sepanjang titik-titik kritis asal maupun tujuan produk dalam rangka terjaminnya keamanan produk pangan tersebut (Dwiyitno, 2016). Menurut ISO 9001/2000, ketertelusuran adalah kemampuan untuk menelusuri kejelasan asal, perlakuan atau riwayat produksi suatu produk. Lebih khusus lagi, pelabelan dan ketertelusuran produk rekayasa genetika merupakan isu penting dan diatur tersendiri sistem distribusinya, khususnya di Negara negara Uni Eropa (EC No. 1829 \& 1830, 2003). Di Indonesia, ketertelusuran diartikan sebagai kemampuan untuk menelusuri riwayat, aplikasi atau lokasi dari suatu produk atau kegiatan untuk mendapatkan kembali data dan informasi melalui suatu identifikasi terhadap dokumen yang terkait seperti diatur dalam Pasal 1 Permen KP No. 01/Men/2007. Tujuan utama dari sistem ketertelusuran adalah untuk mencatat dan mendokumentasikan suatu produk termasuk seluruh bahan yang digunakan dalam proses produksinya, hingga proses pengolahan sampai produk terdistribusi kepada konsumen. Apabila sistem ketertelusuran diterapkan dengan baik, maka penolakan terhadap produk dapat dikurangi sehingga dapat menghemat pengeluaran sebuah industri pangan. Pada sisi lain, dengan terjaminnya kualitas dan keamanan suatu produk berdampak pada meningkatnya kepercayaan konsumen terhadap produk tersebut. Pada prakteknya, sistem ketertelusuran dapat diimplementasikan menggunakan sistem informasi sehingga pengguna mampu melakukan identifikasi sendiri, seperti menggunakan alat electronic data interchange/EDI (Dwiyitno, 2016). Pelaku usaha yang telah menerapkan sistem jaminan mutu Hazard Analysis Critical Control Point (HACCP) juga memungkinkan pengintegrasian sistem $H A C C P$-nya dengan sistem ketertelusuran. Hal ini karena record keeping sebagai salah satu aspek penting sistem ketertelusuran merupakan salah satu di antara 7 prinsip $H A C C P$. Penerapan sistem ketertelusuran telah menjadi bagian yang tidak dapat terpisahkan dari mata rantai produksi dan distribusi produk pangan sehingga sistem ketertelusuran yang berkembang pun menjadi bervariasi, disesuaikan dengan kebutuhan. Pada dasarnya, pemilihan sistem ketertelusuran yang digunakan harus mampu menjamin aspek keamanan produk secara efisien pada beberapa negara. 


\section{Sistem Informasi}

Sistem informasi berarti adalah sebuah sistem yang dilakukan dalam menyediakan informasi ketika hendak mengambil keputusan untuk manajemen dan dalam rangka menjalankan operasional dan prosedur yang terorganisir. Sistem informasi bertujuan untuk menjaga tercapainya pesan atau informasi dari seseorang atau kelompok kepada pihak lain. Beberapa ahli telah mengemukakan pendapat tentang pengertian sistem informasi (Artikelsiana, 2015).

- Alter: sistem informasi adalah sistem sebagai bagian khusus dari sistem kerja ketika manusia atau mesin melaksanakan pekerjaannya menggunakan sumber daya untuk memproduksi barang atau jasa tertentu yang ditujukan untuk pelanggan atau pengguna.

- Henry Lucas: pengertian sistem informasi menurut Henry Lucas adalah sebuah kegiatan dari berbagai prosedur yang terorganisir. Jika sistem tersebut dilaksanakan, maka tersedia informasi yang dapat mendukung terwujudnya pengendalian dan pengambilan keputusan dalam sebuah organisasi atau kelompok tertentu.

- John F Nash: pengertian sistem informasi adalah kombinasi dari beberapa manusia, alat teknologi atau fasilitas, media, pengendalian dan prosedur tang tujuannya menata jaringan komunikasi yang terstruktur, berkesinambungan, dan mempunyai sebuah aturan baku. Tujuannya adalah supaya dapat membantu pihak manajemen mengambil keputusan yang tepat berdasarkan pada pemakai data ekstern dan intern.

- Robert A Leitch: pengertian sistem informasi menurut Robert A Leitch adalah sebuah sistem di dalam suatu organisasi yang menjadi sarana untuk mempertemukan kebutuhan transaksi harian dan hal yang mendukung operasi perusahaan, orang, atau organisasi. Hal ini bersifat manajerial dengan kegiatan berupa penyediaan laporan-laporan yang diperlukan oleh pihak yang bersangkutan.

Secara bahasa, sistem berarti kumpulan orang yang saling melakukan kerjasama dengan melakukan berbagai ketentuan dari aturan yang sifatnya sistematis dan terstruktur untuk membentuk sebuah kesatuan dalam melaksanakn sebuah fungsi demi tercapainya tujuan bersama. Pengertian informasi menurut bahasa adalah data yang dapat diolah menjadi lebih berguna dan mempunyai arti bagi orang atau kelompok yang menggunakan data tersebut, mengurangi ketidakpastian dalam proses untuk mengambil keputusan dari sebuah keadaan.

\section{Quick Response Code}

Quick Response Code sering di sebut $Q R$ Code adalah simbol dua dimensi yang dikembangkan oleh Denso Wave yang merupakan anak perusahaan dari Toyota sebuah perusahaan Jepang pada tahun 1994 (Muharom dkk., n.d.). Tujuan dari $Q R$ Code ini adalah untuk menyampaikan informasi secara cepat dan juga mendapat tanggapan secara cepat. Pada awalnya $Q R$ Code digunakan untuk pelacakan bagian kendaraan untuk manufacturing. Namun sekarang, telah digunakan untuk komersil yang ditujukan pada pengguna telepon seluler. $Q R$ Code adalah perkembangan dari barcode atau kode batang yang hanya mampu menyimpan informasi secara horizontal sedangkan $Q R$ Code mampu menyimpan informasi lebih banyak, baik secara horizontal maupun vertikal.

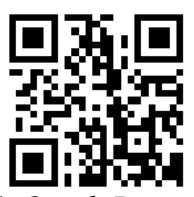

Gambar 1 Quick Response Code

QR Code biasanya berbentuk persegi putih kecil dengan bentuk geometris hitam (dapat dilihat di Gambar 1), meskipun sekarang banyak yang telah berwarna dan digunakan sebagai brand produk.

QR Code memiliki manfaat yang terdapat pada $Q R$ Code menurut Denso (2011) antara lain (Yohana Tri Widayati, 2017):

1. Kapasitas tinggi dalam menyimpan data Sebuah $Q R$ Code tunggal dapat menyimpan sampai 7.089 angka.

2. Ukuran yang kecil dari sebuah $Q R$ Code dapat menyimpan jumlah data yang sama dengan barcode 1D dan tidak memerlukan ruang besar. 
3. Dapat mengoreksi kesalahan tergantung pada tingkat koreksi kesalahan yang dipilih, data pada $Q R$ code yang kotor atau rusak sampai $30 \%$ dapat diterjemahkan dengan baik.

4. Banyak jenis data $Q R$ Code dapat menangani angka, abjad, simbol, karakter bahasa Jepang, Cina atau Korea dan data biner.

5. Kompensasi distorsi $Q R$ Code tetap dapat dibaca pada permukaan melengkung atau terdistorsi.

6. Kemampuan menghubungkan sebuah $Q R$ Code dapat dibagi hingga 16 simbol yang lebih kecil agar sesuai dengan ruang. Simbol-simbol kecil yang dibaca sebagai kode tunggal apabila di scan menurut urutan.

\section{Perancangan Sistem Informasi}

Perancangan Sistem dapat didefenisikan sebagai penggambaran, perencanaan, dan pembuatan sketsa atau pengaturan dari beberapa elemen yang terpisah kedalam satu kesatuan yang utuh dan berfungsi (Jogiyanto HM, 2005). Pengertian perancangan sistem yang lain adalah "Perancangan sistem menentukan bagaimana suatu sistem akan menyelesaikan apa yang mesti diselesaikan (Jogiyanto HM, 2005). Tahap ini menyangkut mengkonfigurasikan dari komponenkomponen perangkat lunak dan perangkat keras dari suatu sistem sehingga setelah instalasi dari sistem akan benar-benar memuaskan rancangan bangun yang telah ditetapkan pada akhir tahap analisa sistem".

Pada dasarnya terdapat enam tahapan dalam perancangan sistem (Leman, 1997), sebagai berikut :

(1) Survey sistem, melalui identifikasi kondisi ekstensi/kebutuhan pengguna, definisi ruang lingkup pekerjaan dan penyusunan studi kelayakan. Apa dan bagaimana suatu sistem beroperasi pada lingkungan kerja nantinya, serta dampak dan pemanfaatan sistem nantinya.

(2) Analisa sistem, suatu proses untuk memakai sistem yang ada dengan menganalisa jabatan dan tugas, proses bisnis, ketentuan/aturan yang ada, masalah dan mencari solusinya, sumber daya dan rencana-rencana perusahaan.

(3) Desain sistem, merupakan rancangan bangunan yang lengkap sebagai penuntun bagi programmer dalam mengembangkan aplikasi. Komponen sistem yang didesain meliputi hardware, software, aplikasi dan gambaran/ urutan tugas.
(4) Pembuatan sistem, mencakup data pembuatan database, program aplikasi dan buku petunjuk penggunaan program aplikasi yang telah dibuat.

(5) Implementasi sistem meliputi proses persiapan sistem, sistem pelatihan, pengujian sistem dan pengoperasian sistem

Tahap perancangan sistem informasi ini yaitu tahapan studi pendahuluan (feasibility study), tahapan analisa sistem, analisis data keluaran dari transaksi yang dicatat. Setelah analisis, dilakukan desain sistem pendefinisian kebutuhan sistem, persiapan untuk rancang bangun (implementasi), menggambarkan bagaimana suatu sistem teknologi informasi dapat dibentuk dapat berupa perencanaan, penggambaran, pembuatan sketsa atau pengaturan dari beberapa elemen yang terpisah kedalam satu kesatuan yang utuh dan berfungsi.

\section{METODE PENELITIAN}

\section{Alur Proses Pengolahan Ikan}

Proses pengolahan ikan terdiri dari proses receiving, proses cutting, proses retouching, proses packing dan proses stuffing. Alur proses pengolahan ikan secara umum terdiri dari penerimaan ikan dari supplier dan penimbangan ikan, pencucian dan pemotongan ikan untuk pembersihan kepala, sirip, insang dan ekor untuk mendapatkan daging ikan berupa loin, dilanjutkan dengan penimbangan dan pelabelan ikan dan penentuan grade ikan, pemotongan ikan untuk membuang bagian yang tidak berguna, penimbangan dan pelabelan loin, pengemasan produk dan pelabelan. Selanjutnya pengiriman produk ke pelanggan. Adapun bagan alur proses pengolahan ikan secara umum dapat dilihat pada gambar 2 .

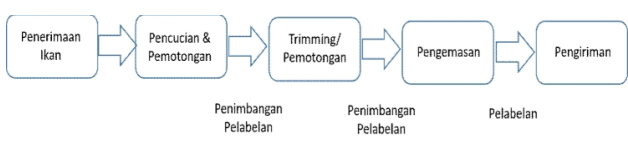

Gambar 2. Alur Proses Pengolahan Ikan 


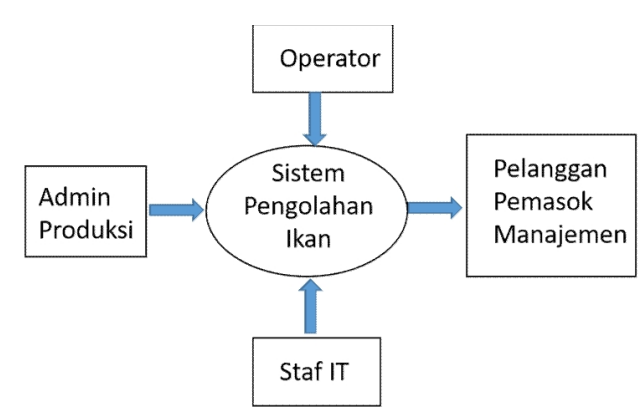

Gambar 3. Gambaran Umum Sistem

Secara garis besar, yang terlibat dalam sistem pengolahan ikan adalah admin produksi, operator, staf IT staf, pemasok dan customer. Operator berinteraksi dengan sistem dalam penginputan data transaksi penerimaan, pemotongan, trimming, pengemasan dan pengiriman ke pelanggan. Staf admin terlibat dalam penginputan data master data. Staf IT terlibat dalam melakukan setting konfigurasi sistem dan penyimpanan database. Staf admin melakukan penerbitan packing list dan customer/pelanggan menerima packing list sebagai bukti pengiriman produk dari perusahaan pengolahan ikan. Pemasok menerima data penerimaan ikan, dan manajemen menerima data kesimpulan dari keseluruhan transaksi penerimaan, pengolahan ikan dan pengiriman ke pelanggan. Staf admin melakukan input master data seperti input data perusahaan, data supplier, data grade, data size produk, data customer dan lainnya, sedangkan operator menginput data penerimaan, pemotongan, retouching, pengemasan dan pengiriman ke pelanggan.

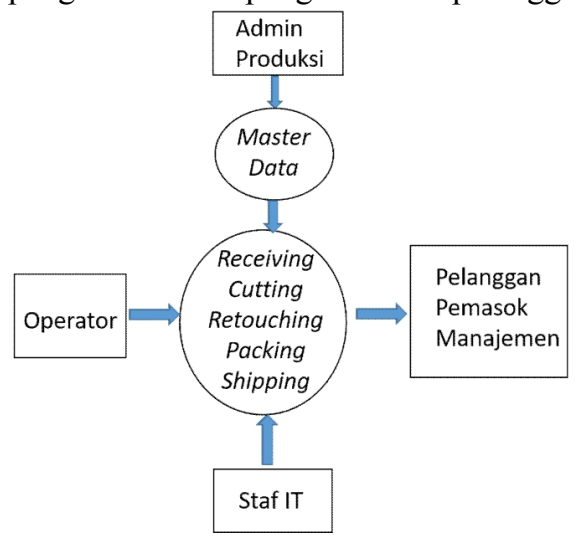

Gambar 4. Gambaran Umum Sistem Transaksi

\section{Rancangan Antarmuka Sistem}

Rancangan antarmuka sistem, menu utama terdiri dari submenu Master Data dan submenu Master Transaksi

Master Data mengelola data master seperti data perusahaan (company master), data user (user setup), data pelanggan (customer setup), data species (species setup), data grade dan ukuran produk, dan data produk. Submenu transaksi terdiri dari transaksi receiving, transaksi cutting, transaksi retouching, transaksi packing dan transaksi stuffing. Hasil dari transaksi stuffing dapat dihasilkan packing list yang merupakan data pengiriman produk ke pelanggan.

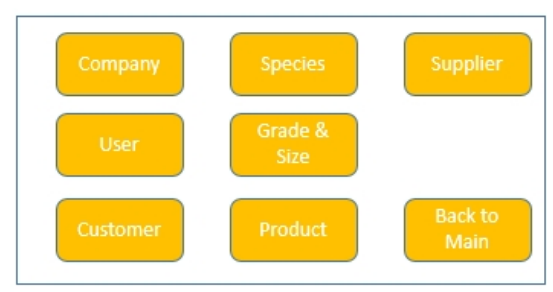

Gambar 5. Rancangan Tampilan Menu Master Data

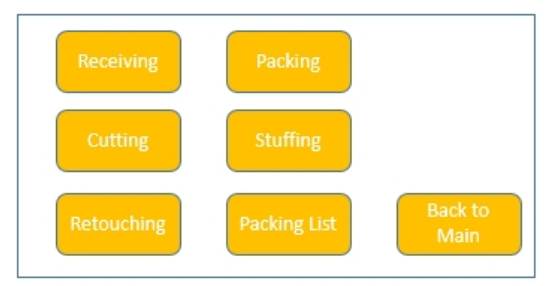

Gambar 6. Rancangan Tampilan Menu Transaksi 


\section{Rancangan Pembentukan Kode Lot} Internal

Kode lot internal digunakan untuk penelusuran data akhir dari produk yang sudah di kirim ke pelanggan dapat di telusuri ke proses sebelumnya sampai pada tahap penerimaan. Kode lot internal dibentuk pada saat penerimaan ikan, dengan format kode lot standar terdiri dari 11 karakter, dan 1 karakter untuk penanda jenis ikan, 1 karakter untuk penanda sertifikat produk.

Kode lot internal dibuat dengan format:

\section{AAABBBCCDDD.E.F}

Keterangan :

AAA : menggambarkan kode batch sebagai lokasi penangkapan ikan

BBB: menggambarkan kode pemasok

$\mathrm{CC}$ : menggambarkan tahun penerimaan ikan 2 angka

DDD: menggambarkan tanggal Julian penerimaan ikan

E : menggambarkan jenis ikan yang diterima, contoh ikan utuh atau loin

F: menggambarkan sertifikat dari produk, contoh: Fair Trade

Kode lot internal ini dibentuk berdasarkan data pemasok yang diinput dalam modul master pemasok. Dalam master pemasok terdapat isian kode batch menggambarkan lokasi penangkapan ikan, kode supplier, asal wilayah pemasok, lokasi pendaratan, negara asal. Informasi ini yang digunakan untuk penelusuran produk selanjutnya.

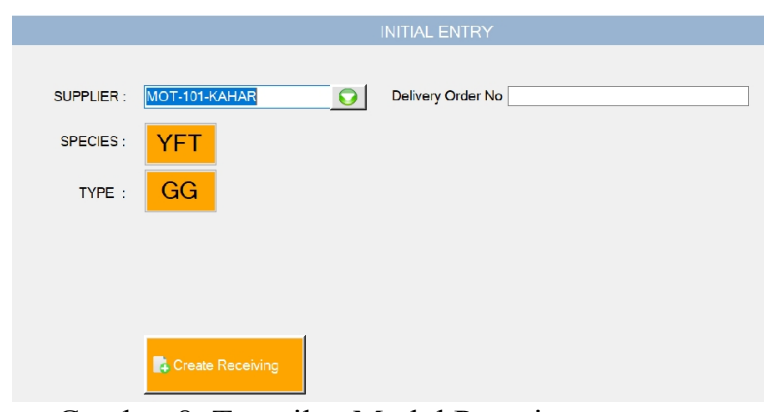

Gambar 8. Tampilan Modul Penerimaan

Pada modul penerimaan, di pilih nama pemasok dalam daftar dropdown, sesuai dengan pemasok yang mengirimkan ikan pada saat itu. Pada saat penerimaan akan terbentuk kode lot internal yang menggambarkan asal dari pemasok tersebut.

Contoh Kode lot internal seperti gambar di bawah ini

\begin{tabular}{|lr|}
\hline $\begin{array}{l}\text { Type : GG } \quad \text { Species : YFT } \\
\text { Internal Lot Code : MOT10118216.1.1 }\end{array}$ & Weighing : \\
Gambar 9. Kode Lot Internal
\end{tabular}

Contoh kode lot internal : MOT10118216.1.1

Dengan keterangan:

MOT : lokasi pendaratan kapal / penangkapan ikan (Morotai Timur)

101 : kode pemasok

18216 : tahun 2018, Julian kalender 216 (4 Agustus)

1 : jenis ikan ( ikan utuh )

1 : kelompok tanggal ( tanggal $1-5$ termasuk kelompok 1 )

\subsection{Tampilan Antarmuka Sistem Informasi} Pengolahan Ikan


Modul penerimaan digunakan untuk transaksi enerimaan ikan dari pemasok oleh unit pengolahan ikan. Tampilan antarmuka modul penerimaan seperti pada gambar 10 .

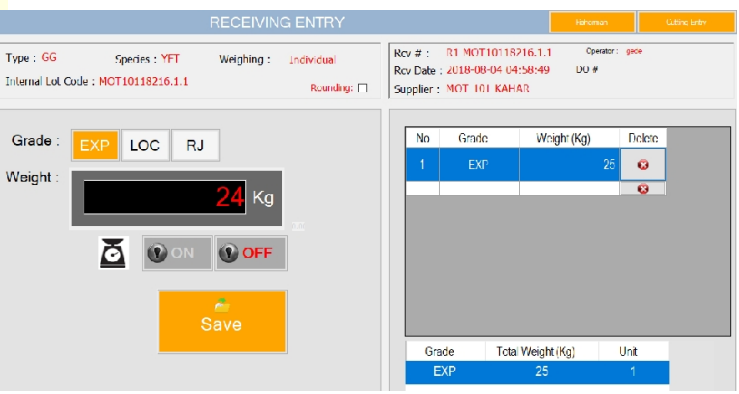

Gambar 10. Tampilan Modul Penerimaan

Gambar 7. Tampilan Master Pemasok 
Sebagai tahap awal, penerimaan ikan berupa ikan utuh dan loin digunakan modul receiving, sistem membuat kode lot internal sebagai kode untuk penelusuran. Internal lot code terdiri dari 12 karakter dimana 3 karakter awal menyatakan wilayah tangkapan/pendaratan, 3 karakter berikutnya menyatakan kode supplier, 2 karakter berikutnya menyatakan tahun proses, 3 karakter menyatakan tanggal proses dalam kalender Julian, dan 1 karakter berikutnya menyatakan jenis ikan baik itu ikan utuh maupun ikan loin, dan jika terdapat supplier yang menerapkan sertifikasi, maka kode 2 karakter di tulis pada bagian paling belakang.

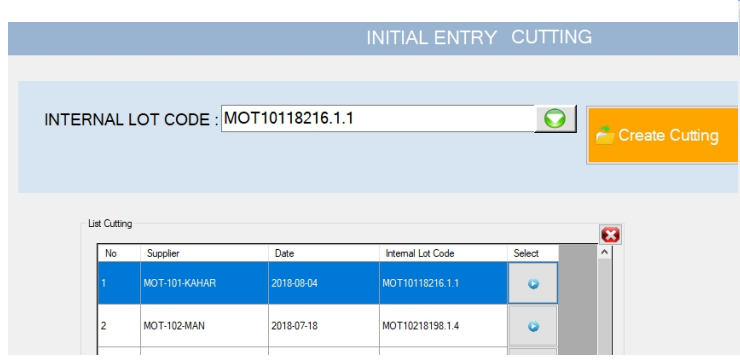

Gambar 11. Tampilan Awal Modul Cutting

Pada modul cutting dipilih kode lot internal yang telah dibuat pada modul penerimaan.

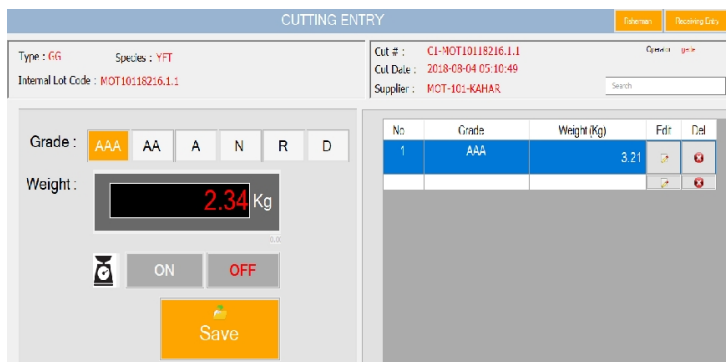

Gambar 12. Tampilan Input Data Modul Cutting

Proses cutting melanjutkan kode lot internal penerimaan, penentuan grade loin, berupa grade export (kualitas tinggi) atau grade lokal (kualitas sedang) atau grade reject (kualitas rendah). Pada modul ini dilakukan penimbangan setiap loin.

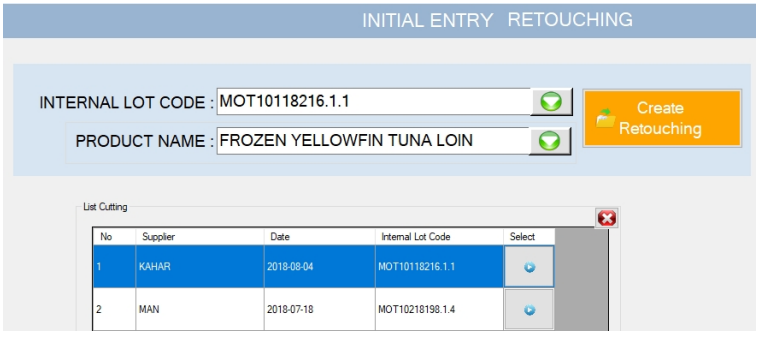

Gambar 13. Tampilan Awal Modul Retouching

Modul retouching merupakan kelanjutan dari proses cutting, melanjutkan kode lot internal dari proses cutting

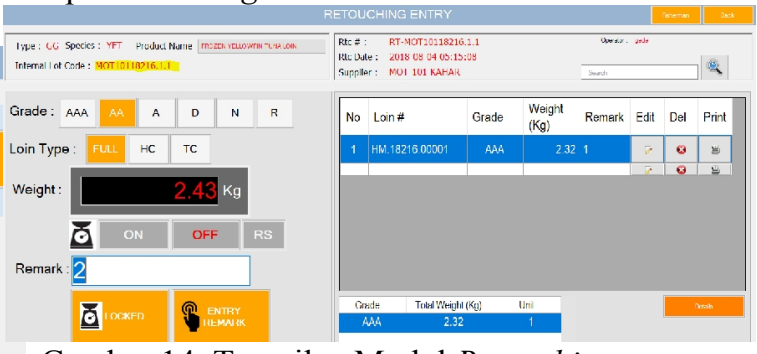

Gambar 14. Tampilan Modul Retouching

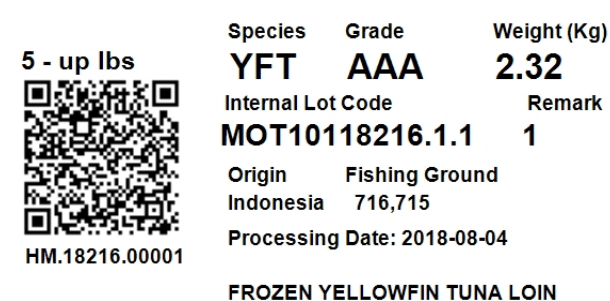

Gambar 15. Tampilan Label Loin Dengan $Q R$ Code

Pada label tersebut terdapat informasi produk dan terdapat juga kode QR apabila dipindai akan menampilkan informasi produk, spesies, grade, berat, kode lot internal, asal ikan, lokasi penangkapan ikan, tanggal pengolahan dan nama produk. Selanjutnya loin yang sudah di kemas, dibekukan dan setelah proses beku maka dikemas ke dalam karton box. Proses pengemasan dilakukan dalam modul packing dengan memindai label loin tersebut dan data otomatis tercatat ke dalam box tersebut. 


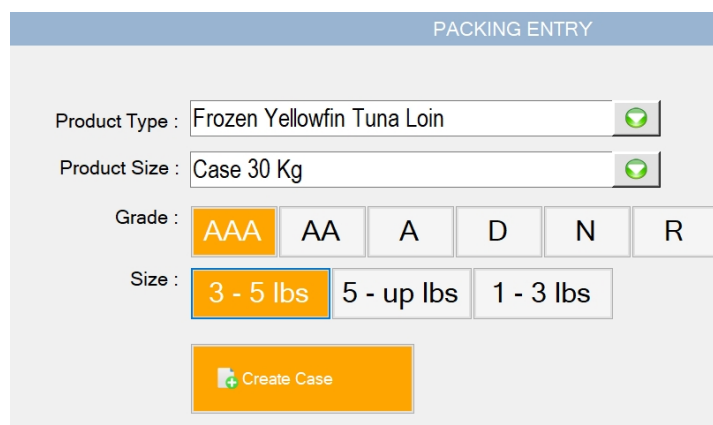

Gambar 16. Tampilan Input Awal Pada Modul Packing

tahap penerimaan, pemotongan, retouching sampai pengemasan, dimana terdapat label produk yang dapat digunakan untuk melakukan penelusuran asal ikan baik informasi pemasok, lokasi penangkapan ikan maupun informasi produksi.

\section{SIMPULAN}

Implementasi sistem penelusuran dengan menggunakan kode QR, dapat diterapkan pada kegiatan pengolahan perikanan dimana dengan kode QR memudahkan dalam menyimpan informasi sekaligus sebagai kode untuk

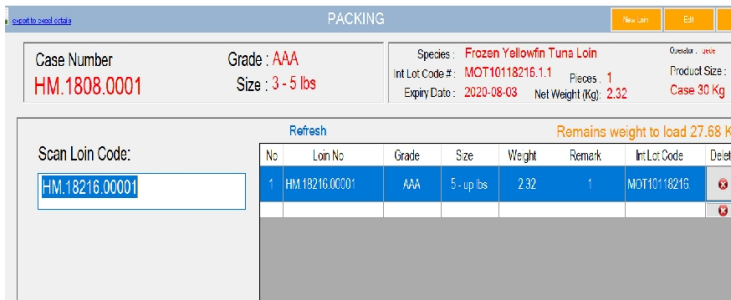

Gambar 17. Tampilan Modul Packing

Apabila kapasitas box sudah terpenuhi, maka dapat di print label box yang berisi $Q R$ Code menyimpan informasi tentang box.

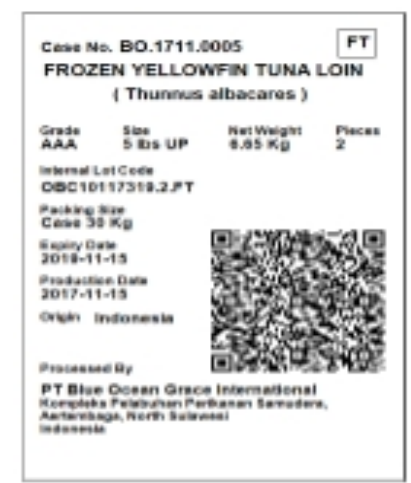

Gambar 18. Tampilan Print Out Label Box

Transaksi yang sudah diinput dapat di lihat pada modul Summary Transaction yang mencatatkan semua transaksi dari penerimaan, pemotongan, retouching sampai packing dengan kode lot internal sebagai kode untuk penelusuran.

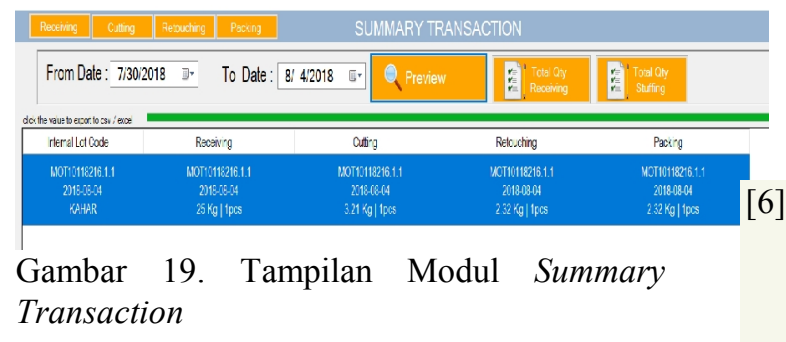
scanning tahap pengolahan lanjutan, proses penginputan data lebih cepat dan proses pengolahan data lebih efisien karena cukup desedengan memindai maka data ikan sudah - otomatis tercatat pada sistem. Penggunaan kode internal lot, memudahkan dalam melakukan penelusuran sumber ikan pada setiap tahap pengolahan ikan, dimana kode internal lot terdiri dari kode wilayah tangkapan ikan, kode supplier, dan tanggal pemrosesan ikan.

\section{DAFTAR PUSTAKA}

[1] Kendall, K.E. dan Kendall, J.E. 2006. Analisis dan Perancangan Sistem Informasi. Versi Bahasa Indonesia. Edisi Kelima. Jilid I. PT. Indeks Kelompok Gramedia. Jakarta.

[2] Tamm EE, Schiller L. Seafood Authenticity and Traceability. 2016. doi:10.1016/B978-0-12-801592-6.000024

[3] Tamm EE, Schiller L, Hanner RH. Seafood Traceability and Consumer Choice. In: Seafood Authenticity and Traceability: A DNA-Based Pespective. 2016. doi:10.1016/B978-0-12-8015926.00002-4

[4] Ibáñez AL. Fish traceability: Guessing the origin of fish from a seafood market using fish scale shape. Fish Res. 2015. doi:10.1016/j.fishres.2015.05.016

[5] Subroto IMI, Taufik M, Gabels R. 2016. Rancang Bangun Sistem Informasi Pelelangan Ikan Berbasis Web Pada Tempat Pelelangan Ikan Kabupaten Situbondo Jawa Timur. Transistor Elektro dan Inform. 2016.

[6] Jogiyanto HM, Prof.,Dr., MBA, Akt. 2005. Analisis Desain Sistem Informasi Pendekatan terstruktur. Andi Offset. Yogyakarta.

Melalui modul summary transaction, dapat di telusuri pengolahan ikan dari awal mulai dari 
[7] Leman.1997. Metodologi Pengembangan Sistem Informasi. PT Elex Media Komputindo: Jakarta

[8] Lumingas, L, J, L. B, Wahono. 2010. Studi Aspek Reproduksi Ikan Madidihang (Yellowfin Tuna), Thunnus albacares (Bonnaterre, 1788) Sebagai Dasar Pengelolaan Perikanan Tuna Yang Berkelanjutan. Simpossium Pengelolaan Perikanan Tuna Berkelanjutan. Bali.

[9] Rahajeng, M. 2012. Ikan Tuna Indonesia. Kementrian Perdagangan Republik Indonesia. Jakarta.

[10] Murniyati, AS dan Sunarman. 2000. Pendinginan, Pembekuan dan Pengawetan Ikan. Kanisius. Yogyakarta. 